\title{
Analisis Kadar Vitamin C Kelopak Rosella (Hibiscus sabdariffa L.) Muda dan Tua yang dikoleksi Dari Berbagai Ketinggian Tempat yang Berbeda
}

\author{
HENI SETYAWATI ${ }^{1}$, M. ALI MUSTOFA ${ }^{1}$ \\ ${ }^{1}$ Tadris Biologi, Fakultas Tarbiyah dan Ilmu Keguruan, Institut Agama Islam Negeri Jember \\ Jl. Mataram No.1 Mangli, Kaliwates, Jember, Jawa Timur. 68136 \\ Email: henisetyawati0787@gmail.com
}

Received 24 December 2017; Received in revised form 17 January 2018;

Accepted 2 February 2018; Available online 3 February 2018

\begin{abstract}
The aims of the research was to know the vitamin $\mathrm{C}$ content in unripe and ripe rosella calyx in three different altitudes. Rosella calyx which were used in this research were taken from three different altitudes. There were Glagah beach (7 masl), KP4 Berbah (126 masl), and Samigaluh (600 masl). The vitamin $\mathrm{C}$ content were determined by titration method using 2,6dichlorophenolindophenol. The result of this research showed that vitamin $\mathrm{C}$ content in unripe rosella calyx was not significantly different. The highest vitamin $C$ content in ripe rosella calyx at $7 \mathrm{~m}$ and $600 \mathrm{~m}$ altitude were not significantly different. And the vitamin $\mathrm{C}$ content in unripe and ripe rosella calyx at 7 masl and 600 masl were also not significantly different. Vitamin C content in unripe rosella calyx at 126 masl was $2,269 \mathrm{mg} / \mathrm{g}$, higher than the ripe $(1,316 \mathrm{mg} / \mathrm{g})$. It could be concluded that the altitude and the age of calyx influence vitamin $\mathrm{C}$ content in rosella calyx.
\end{abstract}

Keywords: altitude, rosella, vitamin C

\section{INTISARI}

Tujuan penelitian ini adalah untuk mengetahui kadar vitamin $\mathrm{C}$ yang terkandung dalam kelopak bunga rosella yang berumur muda dan tua pada tiga ketinggian tempat. Kelopak bunga rosella yang dipakai dalam penelitian ini diambil dari tiga ketinggian tempat yaitu Pantai Glagah (7 mdpl), KP4 Berbah (126 mdpl) dan Samigaluh (600 mdpl). Kadar vitamin C ditentukan dengan metode titrasi dengan 2,6-diklorofenol indofenol. Untuk menghilangkan warna larutan sampel disaring dengan karbon aktif. Hasil penelitian menunjukkan bahwa kadar vitamin $\mathrm{C}$ kelopak bunga rosella muda tidak berbeda nyata pada tiga ketinggian tempat. Kadar vitamin $\mathrm{C}$ kelopak bunga rosella tua tertinggi terdapat pada ketinggian 126 mdpl. Kadar vitamin $C$ kelopak bunga rosella tua pada ketinggian 7 mdpl dan 600 mdpl tidak jauh berbeda. Kadar vitamin $\mathrm{C}$ kelopak bunga rosella muda dan tua pada kadar vitamin $C$ kelopak bunga rosella muda $2,269 \mathrm{mg} / \mathrm{g}$, lebih tinggi dibanding tua $(1,316 \mathrm{mg} / \mathrm{g})$. Dengan ini dapat disimpulkan bahwa ketinggian tempat dan umur kelopak mempengaruhi kadar vitamin C kelopak bunga rosella.

Kata kunci: ketinggian tempat, rosella, vitamin C

\section{PENDAHULUAN}

Vitamin $\mathrm{C}$ atau asam askorbat merupakan senyawa organik yang tidak dapat disintesis oleh tubuh dan dibutuhkan dalam jumlah sedikit sehingga harus diperoleh dari makanan. Vitamin ini larut dalam air, terlebih pada musim hujan, kadarnya akan mengalami penurunan (Daryono dkk., 2016) dan paling labil karena mudah rusak oleh adanya kontak dengan udara, panas, dan logam. Vitamin C bermanfaat sebagai koenzim dan antioksidan yang efektif mengatasi radikal bebas di dalam tubuh. Asam askorbat mempunyai kemampuan reduksi yang kuat dan bertindak sebagai antioksidan dalam reaksi-reaksi hidroksilasi (Almatsier, 2002; Rezvani et al., 2012). Jumlah asam askorbat sangat bervariasi sesuai dengan sumbernya. Buah mentah lebih 
banyak mengandung vitamin $\mathrm{C}$, sedangkan semakin tua buah, kandungan vitamin C semakin berkurang (Kishore et al., 2011).

Saat ini, kelopak rosella (Hibiscus sabdariffa L.) telah banyak diminati oleh masyarakat karena memiliki manfaat dan bernilai ekonomis. Kelopak bunga rosella berwarna merah tua, tebal, berair dan berasa sangat masam. Kelopak bunga rosella diproses menjadi jeli, saus, teh sirup, selai, puding, dan manisan serta diolah menjadi produk minuman dalam bentuk sirup maupun teh. Penjual jamu tradisional pada umumnya menjual rosella kering (Ali $d k k ., 2013$ ).

Hampir semua bagian tanaman rosella memiliki manfaat, mulai dari biji, kelopak, bunga, batang, akar, hingga daun. Dari semua bagian tersebut, kelopak bunga paling banyak dimanfaatkan baik dalam keadaan segar maupun setelah dikeringkan. Kelopak segar kaya akan ribovlavin, asam askorbat, niacin, karoten, kalsium dan besi sebagai nutrien penting (Qi et al., 2005).

Hasil observasi menunjukkan bahwa budidaya rosella dapat dijumpai di dataran rendah, tengah, dan tinggi. Penelitian Fatchurrozak $d k k$., (2013) menyatakan bahwa ketinggian tempat berpengaruh terhadap kandungan vitamin $\mathrm{C}$ dan antioksidan pada buah Carica pubescens di dataran tinggi Dieng. Kadar vitamin C dan antioksidan terbesar terdapat pada buah Carica pubescens yang ditanam pada pada ketinggian 2400 mdpl.

Berdasarkan uraian diatas maka peneliti melakukan penelitian mengenai analisis kadar vitamin $\mathrm{C}$ kelopak bunga rosella ditinjau dari umur dan ketinggian tempat tanam. Tujuan dari penelitian ini adalah untuk mengetahui kadar vitamin $\mathrm{C}$ kelopak bunga rosella pada tiga ketinggian tempat serta untuk mengetahui adanya perbedaan kadar vitamin $\mathrm{C}$ kelopak bunga rosella muda dan tua pada masingmasing ketinggian tempat.

\section{METODE}

Penentuan kandungan Vitamin C dilakukan dengan metode 2,6-D. Tahapan ini meliputi pembuatan dan pengujian larutan standar, pembuatan dan pengujian larutan blangko, serta pengukuran kadar vitamin $\mathrm{C}$ pada sampel kelopak bunga rosella.

Pembuatan dan pengujian larutan standar. Bubuk asam askorbat sebanyak 0,02 $\mathrm{g}$ dilarutkan dengan akuades dan diencerkan menjadi $100 \mathrm{ml}$ dalam labu ukur $100 \mathrm{ml}$. Kemudian diambil $5 \mathrm{ml}$ larutan dan dimasukkan ke dalam erlenmeyer, ditambah 1 $\mathrm{ml}$ asam asetat glasial dan dititrasi dengan larutan 2,6-D sampai terbentuk warna merah muda permanen.

Pembuatan dan pengujian larutan blangko. Pengujian larutan langko dilakukan dengan cara yang sama seperti standar, namun larutan standar diganti dengan akuades.

Pengukuran kadar vitamin C sampel. Sampel (kelopak bunga rosella) baik muda maupun tua $5 \mathrm{~g}$, kemudian digerus dan diencerkan sampai $100 \mathrm{ml}$. Larutan ditambah karbon aktif sampai warna merah hilang, kemudian disaring. Larutan tersebut diambil sebanyak $5 \mathrm{ml}$, kemudian ditambah $1 \mathrm{ml}$ asam asetat glasial dan $1 \mathrm{ml}$ kloroform, dititrasi dengan larutan 2,6-D sampai terbentuk warna merah muda permanen. Masing-masing larutan (larutan standar, sampel, dan blangko) dititrasi sebanyak dua kali. Masing-masing volume titran dicatat dan digunakan untuk menghitung kadar vitamin C. Kadar vitamin C dapat dihitung dengan rumus:

\footnotetext{
Keterangan:

$\mathrm{K}=$ kadar vitamin $\mathrm{C}(\mathrm{mg} / \mathrm{g})$

$\mathrm{T}=$ titran sampel $(\mathrm{ml})$

ST $=$ titran standar $(\mathrm{ml})$

$\mathrm{BL}=$ titran standar $(\mathrm{ml})$

C = kadar larutan standar
} 


\section{HASIL}

Kadar vitamin C kelopak bunga rosella (Hibiscus sabdariffa L.) muda dan tua pada

tiga ketinggian tempat dapat dilihat pada gambar 2 .

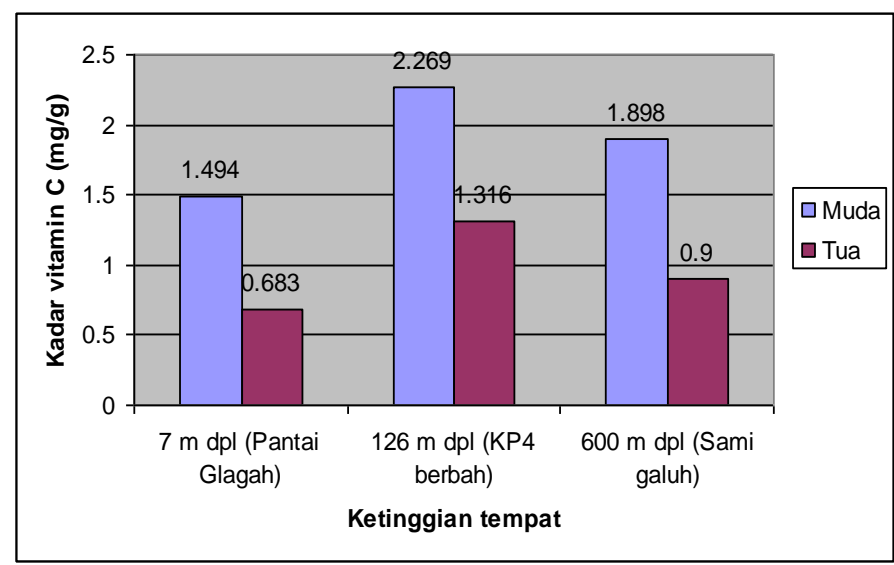

Gambar 2. Kadar vitamin C kelopak bunga rosella (Hibiscus sabdariffa L.)

Berdasarkan gambar 2 diketahui bahwa kadar vitamin $\mathrm{C}$ kelopak bunga rosella tertinggi terdapat pada kelopak bunga rosella yang ditanam pada ketinggian $126 \mathrm{mdpl}$, sedangkan kadar vitamin $\mathrm{C}$ terendah terdapat pada kelopak bunga rosella yang ditanam pada ketinggian 7 mdpl.

Hasil kadar vitamin C tersebut setelah dianalisis statistik maka diperoleh hasil seperti tertera pada tabel 1 .

Tabel 1.Kadar vitamin C kelopak bunga rosella pada tiga ketinggian tempat

\begin{tabular}{cccc}
\hline \multirow{2}{*}{ Nama tempat } & Ketinggian tempat & \multicolumn{2}{c}{ Kadar vitamin C (mg/g) } \\
\cline { 3 - 4 } & $($ mdpl) & Muda & Tuar \\
\cline { 3 - 4 } & 7 & $1,494^{\mathrm{a}}$ & $0,683^{\mathrm{a}}$ \\
\hline Pantai Glagah & 126 & $2,269^{\mathrm{a}}$ & $1,316^{\mathrm{b}}$ \\
\hline KP4 Berbah & 600 & $1,898^{\mathrm{a}}$ & $0,9^{\mathrm{a}}$
\end{tabular}

Angka yang diikuti huruf yang sama pada setiap kolom menunjukan tidak berbeda nyata pada aras 5\%, N=3

Berdasarkan tabel 1 dapat diketahui bahwa kadar vitamin $\mathrm{C}$ kelopak bunga rosella muda pada ketiga ketinggian tempat tidak berbeda, namun kadar vitamin $\mathrm{C}$ kelopak bunga rosella tua pada ketinggian $7 \mathrm{mdpl}$ dengan 600 mdpl serta 126 mdpl dengan 600 mdpl tidak berbeda nyata. Kadar vitamin C tertinggi terdapat pada kelopak bunga rosella tua yang ditanam pada ketinggian $126 \mathrm{mdpl}$ (KP4 Berbah).

Tabel 2. Kadar vitamin C kelopak bunga rosella muda dan tua pada masing-masing ketinggian tempat.

\begin{tabular}{cccc}
\hline \multirow{2}{*}{ Umur } & \multicolumn{3}{c}{ Kadar vitamin $\mathbf{C}(\mathbf{m g} / \mathbf{g})$} \\
\cline { 2 - 4 } & $\mathbf{7}$ & Ketinggian tempat $(\mathbf{m d p l})$ \\
\cline { 2 - 4 } & $1,494^{\mathrm{a}}$ & $\mathbf{1 2 6}$ & $\mathbf{6 0 0}$ \\
\hline Muda & $0,683^{\mathrm{a}}$ & $2,269^{\mathrm{a}}$ & $1,898^{\mathrm{a}}$ \\
\hline Tua & $1,316^{\mathrm{b}}$ & $0,9^{\mathrm{a}}$ \\
\hline
\end{tabular}

Angka yang diikuti huruf yang sama pada setiap kolom menunjukkan tidak berbeda nyata pada aras $5 \%, \mathrm{~N}=3$ 
Berdasarkan tabel 2 dapat diketahui bahwa vitamin $\mathrm{C}$ kelopak bunga rosella muda dengan tua pada ketinggian $7 \mathrm{mdpl}$ dan 600 mdpl tidak berbeda nyata, namun pada ketinggian 126 mdpl kadar vitamin C kelopak bunga rosella muda lebih tinggi dibanding yang tua.

\section{PEMBAHASAN}

Kadar vitamin $\mathrm{C}$ dalam penelitian ini ditentukan dengan metode titrasi 2,6diklorifenol indofenol. Keuntungan metode ini adalah hasil yang diperoleh cukup spesifik karena menggunakan larutan standar dari asam askorbat. Dasar penentuan kadar vitamin C dengan metode ini adalah adanya oksidasi asam askorbat oleh 2,6-diklorifenol indofenol yang merupakan bahan berwarna menjadi asam dehidroaskorbat. Pada waktu yang sama 2,6-diklorifenol indofenol menjadi bahan yang tidak berwarna (leucodye). Kekuatan mereduksi vitamin $\mathrm{C}$ terdapat pada atom hidrogen yang terikat pada atom C-2 dan C-3. Dalam keadaan teroksidasi, kedua atom $\mathrm{H}$ ini lepas sehingga vitamin $\mathrm{C}$ kehilangan aktivitasnya sebagai reduktor.

Larutan 2,6-diklorifenol indofenol dalam suasana netral atau basa akan berwarna biru, sedangkan dalam suasana asam akan berwarna merah muda. Apabila semua asam askorbat telah mereduksi 2,6-diklorifenol indofenol, maka kelebihan 2,6-diklorifenol indofenol akan terlihat dengan terjadinya pewarnaan.

Dalam penelitian ini karbon aktif digunakan untuk menghilangkan warna sampel, sehingga titik akhir titrasi mudah ditentukan. Vitamin $\mathrm{C}$ lebih stabil dalam keadaan asam. Juga digunakan asam asetat glasial untuk memberikan suasana asam. Selain itu kondisi asam akan meningkatkan spesifitas reaksi penghilangan warna 2,6diklorifenol indofenol oleh vitamin $\mathrm{C}$ karena substansi yang mengganggu akan bereaksi lambat.

Berdasarkan hasil yang diperoleh diketahui bahwa kadar vitamin $\mathrm{C}$ kelopak bunga rosella muda lebih tinggi dibanding yang tua. Hal ini sesuai dengan teori yang dikemukakan oleh Gaman dan Sherrington, 1992 serta Winarno, 1991 dalam Winarti
(2006) bahwa buah yang masih mentah lebih banyak memiliki kandungan vitamin $\mathrm{C}$. Semakin tua buah, kandungan vitamin $\mathrm{C}$ semakin berkurang. Namun setelah uji DMRT maka hanya pada ketinggian 126 mdpl yang sesuai dengan teori tersebut.

Rosella tumbuh baik pada tanah berpengairan baik dan subur dalam kondisi penuh cahaya. Rosella membutuhkan tanah yang permeabel. Rosella dapat beradaptasi dengan berbagai jenis tanah, namun tidak toleran terhadap keteduhan. Kadar vitamin C kelopak bunga rosella muda pada ketinggian tempat tidak berbeda. Kadar vitamin C tertinggi terdapat pada kelopak bunga rosella tua yang ditanam pada ketinggian $126 \mathrm{mdpl}$ (KP4 Berbah). Kandungan vitamin $\mathrm{C}$ yang tinggi terkait dengan tingginya karbohidrat (glukosa dan laktosa) yang dapat dimanfaatkan sebagai prekusor untuk pembentukan vitamin C (Rohyani $d k k ., 2015)$. Perbedaan kadar vitamin $\mathrm{C}$ ini dapat disebabkan karena kondisi lingkungan, antara lain kondisi tanah. Walaupun rosella toleran terhadap berbagai jenis tanah namun pada penelitian ini tekstur tanah pada ketiga ketinggian sangat berbeda. Tekstur tanah akan mempengaruhi daya serap air dan hara, sehingga akan berdampak pada proses fisiologi tanaman rosella, seperti proses fotosintesis. Kadar vitamin C dipengaruhi oleh faktor-faktor yang mempengaruhi fotosintesis. Hal ini disebabkan karena asam askorbat disintesis dari glukosa. Terganggunya fotosintesis glukosa akan mempengaruhi produksi vitamin $\mathrm{C}$ oleh tanaman. Ketinggian tempat berpengaruh terhadap proses metabolisme tanaman antara lain proses biokimia dan sintesis metabolit sekunder. Semakin tinggi ketinggian tempat maka semakin tinggi stress lingkungan, misalnya suhu semakin rendah, kelembaban semakin tinggi, lama penyinaran semakin sedikit. Sedangkan semakin rendah ketinggian tempat, maka intensitas cahaya serta suhu semakin tinggi, sehingga vitamin $\mathrm{C}$ semakin mudah teroksidasi. Setiap tanaman membutuhkan kondisi lingkungan optimum tertentu untuk menjalankan proses metabolismenya, sehingga mampu menghasilkan senyawa aktif yang optimum. 


\section{KESIMPULAN}

Ketinggian tempat dan umur kelopak mempengaruhi kadar vitamin $\mathrm{C}$ kelopak bunga rosella (Hibiscus sabdariffa L.).

\section{UCAPAN TERIMA KASIH}

Penulis menyampaikan terima kasih yang sebesar-besarnya kepada Prof. Sukarti Moeljopawiro, Ph.D yang telah membimbing penulis selama penelitian.

\section{DAFTAR PUSTAKA}

Almatsier S. 2002. Prinsip-prinsip Dasar Ilmu Gizi. Jakarta: PT Gramedia Pustaka Utama.

Ali F, Ferawati F, Arqomah R. 2013. Ekstraksi Zat Warna dari Kelopak Bunga Rosella (Study Pengaruh Konsentrasi Asam Asetat dan Asam Sitrat). Jurnal Teknik Kimia. vol 19(1): 26-34.

Daryono BS, Maryanto SD, Nissa S, Aristya GR. 2016. Analisis Kandungan Vitamin Pada Melon (Cucumis melo L.) Kultivar Melodi Gama 1 dan Melon Komersial. Biogenesis. vol 4(1): 1-9. https://doi.org/10.24252/bio.v4i1.1113

Fatchurrozak, Suranto, Sugiyarto. 2013. Pengaruh Ketinggian Tempat Terhadap Kandungan Vitamin $\mathrm{C}$ dan Zat Antioksidan Pada Buah Carica pubescens di Dataran Tinggi Dieng. El-Vivo. vol 1(1): 24-31.
Kishore RK, Halim AS, Syazana MSN, Sirajudeen KNS. 2011. Tualang honey has higher phenolic content and greater radical scavenging activity compared with other honey sources. Nutrition Research. vol 31(4): 322-325. https://doi.org/10.1016/j.nutres.2011.03.0 $\underline{01}$

Qi Y, Chin KL, Malekian F, Berhane M, Gager J. 2005. Biological Characteristics, Nutritional and Medicinal Value of Roselle, Hibiscus sabdariffa. Circular UFNR, No.604. Los Angeles: Agricultural Research and Extension Center. www.suagcenter.com. diakses pada Desember 2017

Rezvani HT, Moradi P, Soltani F. 2012. The effect of nitrogen fixation and phosphorus solvent bacteria on growth physiology and vitamin $\mathrm{C}$ content of Capsicum annum $\mathrm{L}$. Iranian Journal of Plant Physiology. vol 3(2): 673-682.

Rohyani IS, Aryanti E, Suripto. 2015. Potensi Nilai Gizi Tumbuhan Pangan Lokal Pulau Lombok Sebagai Basis Penguatan Ketahanan Pangan Nasional. Pros Sem Nas Masy Biodiv Indon. vol 1(7): 16981701.

https://doi.org/10.13057/psnmbi/m01073 $\underline{0}$

Winarti S. 2006. Minuman Kesehatan. Surabaya: Trubus Agrisarana. hal 68-69. 